Reprod. Nutr. Dévelop., 1981, 21 (6 A), 989-997.

\title{
Changes in plasma gonadotropin after ovariectomy and estradiol supplementation at different stages at the end of the reproductive cycle in the rainbow trout (Salmo gairdneri R.)
}

\author{
par Marie-Charlotte BOMMELAER, R. BILLARD, B. BRETON * \\ Laboratoire de Physiologie des Poissons, I.N.R.A. \\ 78350 Jouy en Josas, France. \\ * Campus de Beoulieu, 35042 Rennes, France.
}

Summary. To determine the effect of gonadal feedback on plasma GTH level, female rainbow trout were ovariectomized at three stages at the end of the reproductive cycle: at the end of vitellogenesis, during germinal vesicle migration and during the post-ovulatory period.

A group of controls and one of castrates in each experiment were given an injection of physiological salt solution, and a third group of castrates was supplemented with estradiol$17 \beta\left(E_{2}\right)$ twice a week $(200 \mu \mathrm{g} / \mathrm{kg})$ from the day of surgery. The blood was sampled twice a week, and the GTH measured by RIA.

At the end of vitellogenesis, castration induced a significant rise in the gonadotropic hormone level ( $P<0.001$ from post-surgical day 5 ), and that response, unimpeded by $E_{2}$, was homogeneous in all the fish. During germinal vesicle migration, the response to castration and to supplementary $E_{2}$ varied with the individual. Ovariectomy induced a significant increase in GTH $(P<0.005$ from day 3$)$, but that increase was immediate in 5 females and delayed in the other $4 ; E_{2}$ prevented GTH rise in only 6 females. At the post-ovulatory period we found no significant difference between the control fish and the castrates and $E_{2}$, at least temporarily, prevented the post-ovulatory rise in GTH which is usually found in trout.

\section{Introduction.}

Negative gonadal feedback on the secretion of plasma GTH in fish has been demonstrated in male rainbow trout : plasma GTH is higher after bilateral castration, but response intensity and duration vary according to the stage of the sexual cycle (Billard, Richard and Breton, 1976 ; Billard and Peter, 1977 ; Billard, 1978). The effect of steroid supplementation also depends on the stage of this cycle. During spermiation 
when the pituitary is less receptive to LRH stimulation (Weil et al., 1978), a non-steroid factor present in the seminal fluid seems to at least partly inhibit the GTH increase which follows castration (Breton and Billard, 1980).

Analysis of experimental data on females indicates negative feedback between the gonads and the pituitary. De Vlaming (1974), using estrogens, attempted to stimulate oogenesis in females and Dadzie and Hyder (1976) observed compensatory ovarian hypertrophy in Tilapia after unilateral ovariectomy which was suppressed by methallibure. Cytological studies of the pituitary have shown that castration cells appear after gonadectomy, but do not occur in the presence of estradiol benzoate (Sundararaj and Goswami, 1968 ; McBride and Van Overbeeke, 1969 ; Febvre and Lafaurie, 1971 ; Ueda and Takahashi, 1980 ; Peute ef al., 1980). However, estradiol benzoate can have a tropic effect on the gonadotropic cells of intact female eels (Olivereau and Chambolle, 1978 ; Olivereau and Olivereau, 1979a, b) or of juvenile trout (Crim and Evans, 1979). Moreover, clomiphene citrate treatment may cause circulatory GTH (Breton, Jalabert and Fostier, 1975) and ovulation (Pandey and Hoar, 1972) to increase. This anti-estrogen acts by increasing hypothalamic $\mathrm{GnRH}$ activity (Singh and Singh, 1979).

Finally, Crim and Idler (1978), Whitehead ef al. (1978) and Fostier et al. (1978), using analytical studies to compare changes in the amounts of GTH and of steroids of putative ovarian origin, have shown a positive correlation between GTH and $E_{2}$ levels during vitellogenesis, while Billard ef al. (1978) have shown a negative correlation at the time of ovulation.

The present study deals with the question of gonadal feedback on GTH secretion in female rainbow trout at three different stages during the last part of the reproductive cycle. Castration experiments and $17 \beta-E_{2}$ supplementation were carried out (i) at the end of vitellogenesis when the $E_{2}$ level was maximal or decreasing and the GTH level was relatively low (ii) at the stage of germinal vesicle migration (onset of ocyte maturation : Jalabert et al., 1976 ; Billard ef al., 1978), when the $E_{2}$ level was decreasing and the GTH level increasing, and (iii) at the post-ovulatory stage when the $E_{2}$ level was hardly detectable and the GTH level increased considerably.

\section{Material and methods.}

Brood females from the Gournay-sur-Aronde experimental fish-farm were brought to the laboratory 10 to 15 days before surgery. Throughout the experiment, they were kept in experimental tanks. The water was filtered, re-used and disinfected with UV (Maisse, Dorson and Torchy, 1980).

The experimental protocol presented in table 1 shows the number of experimental lots and the treatments during the three castration periods. The same control animals were used throughout the reproductive cycle, but because of a high mortality rate at the end of experiment 2, six new females of known ovulation time were introduced into the control group of experiment 3. Analysis of variance showed that the plasma GTH level at that time in the «old » and the « new » control fishes was not significantly different. 
TABLE 1

Experimental protocol

\begin{tabular}{|c|c|c|c|}
\hline Experiment & 1 & 2 & 3 \\
\hline Stage & End of vitellogenesis & Oocytes maturation & Post-ovulation \\
\hline Female mean weight & $800 \mathrm{~g}$ & $1200 \mathrm{~g}$ & $1200 \mathrm{~g}$ \\
\hline Time of castration & October & December & mid-January/mid-February \\
\hline Length of experiment & 12 days & 14 days & 21 days \\
\hline \multirow{4}{*}{ Experiment groups } & $\begin{array}{l}\text { Controls }\left(n_{1}=45\right)-\left(n_{2}=11\right) \\
\text { given a } 7 \text { p. } 1000 \mathrm{NaCl} \text { solution } \\
(1 \mathrm{ml} / \mathrm{kg}) \text { twice a week }\end{array}$ & same controls $\left(n_{2}=9\right)$ & same + new controls \\
\hline & $\begin{array}{l}\text { Sham }\left(n_{1}=15\right)-\left(n_{2}=12\right) \\
\text { given a } 7 \text { p. } 1000 \mathrm{NaCl} \text { solution } \\
(1 \mathrm{ml} / \mathrm{kg}) \text { twice a week }\end{array}$ & & \\
\hline & $\begin{array}{l}\text { Castrated }\left(n_{1}=15\right)-\left(n_{2}=14\right) \\
\text { given a } 7 \text { p. } 1000 \mathrm{NaCl} \text { solution } \\
(1 \mathrm{ml} / \mathrm{kg}) \text { twice a week }\end{array}$ & $\begin{array}{l}\text { Castrated }\left(n_{1}=15\right)-\left(n_{2}=6\right) \\
\text { given a p. } 1000 \mathrm{NaCl} \text { solution } \\
(1 \mathrm{ml} / \mathrm{kg} \mathrm{twice} \mathrm{a} \mathrm{week})\end{array}$ & $\begin{array}{l}\text { Castrated }\left(n_{1}=n_{2}=15\right) \\
\text { given a } 7 \text { p. } 1000 \mathrm{NaCl} \text { solution } \\
(1 \mathrm{ml} / \mathrm{kg}) \text { twice a week }\end{array}$ \\
\hline & $\begin{array}{l}\text { Castrated }+17 \beta-E_{2}\left(n_{1}=15\right)- \\
\left(n_{2}=11\right) \text { given } 200 \mu g 17 \beta-E_{2} / \mathrm{kg} \\
\text { twice a week }\end{array}$ & $\begin{array}{l}\text { Castrated }+17 \beta-E_{2}\left(n_{1}=15\right)- \\
\left(n_{2}=6\right) \text { given } 200 \mu g 17 \beta-E_{2} / \mathrm{kg} \\
\text { Iwice a week }\end{array}$ & $\begin{array}{l}\text { Castrated }+17 \beta-E_{2}\left(n_{1}=n_{2}=15\right) \\
\text { given } 200 \mu g 17 \beta-E_{2} / \mathrm{kg} \text { twice a week }\end{array}$ \\
\hline
\end{tabular}

$n_{1}=$ number of fish at the beginning of the experiment.

$n_{2}=$ number of fish at the end of the experiment.

The «old» females were sorted twice a week to determine the stage of germinal vesicle migration and afterwards once a week to detect the time of ovulation. The « new » fish, sorted twice a week to detect the time of ovulation, were then isolated and ovariectomized at the most 3 days later. On the day the ovulated females were sorted, their eggs were expelled by abdominal massage.

After being anesthetized with phenoxyethanol $\left(0.3 \mathrm{ml} / \mathrm{l} \mathrm{H}_{2} \mathrm{O}\right)$, the fish were put under permanent gill perfusion on the operating table using $10^{\circ} \mathrm{C}$ water containing the same concentration of anesthesia. The common cavity was opened 2 to $4 \mathrm{~cm}$ immediately behind the pectoral fins, exposing the ovary whose posterior and anterior parts were excised ; pressure of the index finger prevented hemorrhaging. When the experiment was over, castration integrity was checked. Sham surgery was carried out only in the first experiment; we opened the abdominal wall, examined the ovaries and closed the incision with a woven nylon thread (Bruneau liganyl no. 3). The ovariectomized females were given an intramuscular (IM) injection of 30000 units of penicillin per $\mathrm{kg}$ of body weight ; subsequently, they were kept in groups of 6 to 8 per 450 -liter tank. Instead of the penicillin, the control fish received a 7 p. $1000 \mathrm{NaCl}$ solution.

Blood samples $(0.5 \mathrm{ml}$ of blood from the caudal vein) were taken before surgery and then twice a week with an heparinized syringe (100 IU filtered heparin $/ \mathrm{ml}$ ) from females anesthetized with phenoxyethanol $\left(0.3 \mathrm{ml} / \mathrm{l}\right.$ of $\left.\mathrm{H}_{2} \mathrm{O}\right)$. After centrifugation at $1800 \times \mathrm{g}$ for $20 \mathrm{~min}$, the plasma was stored at $-20^{\circ} \mathrm{C}$ until assay. The estradiol (Roussel) was first dissolved in $90^{\circ}$ ethanol $(1 \mathrm{mg} / \mathrm{ml})$ then diluted in a 7 p. 1000 saline solution the day of treatment so that $200 \mu \mathrm{g} / \mathrm{kg}$ of crystalline $E_{2}$, suspended in a volume of not more than $1 \mathrm{ml}$, was injected. 
The concentrations of gonadotropic « maturational » hormone salmonid GTH (s-GTH) were determined by radioimmunoassay. The assay method used for s-GTH was the same as that used for cyprinid GTH (Breton et al., 1971). The antibody against trout GTH (Breton, Jalabert and Reinaud, 1976) was used at a final concentration of $0.5 .10^{-5}$; the GTH used for ${ }^{125}$ l labelling and the standard was purified from Oncorhynchus tschawystcha pituitary (Breton, Prunet and Reinaud, 1978).

The mean GTH values are shown either with the 95 p. 100 standard deviation or with the extreme values when there are a small number of data. Variance analysis and the t-test were used ; the Mann-Whitney U-test was employed to statistically compare heterogeneous data (fig. 3).

\section{Results.}

Experiment 1 : Castration at the end of vitellogenesis. - After ovariectomy, all the females (fig. 1) showed a significant elevation of the circulating GTH from post-surgical day 5 ( $P<0.001$ compared to the controls) which only returned to the basal level after 3 weeks (fig. 1).

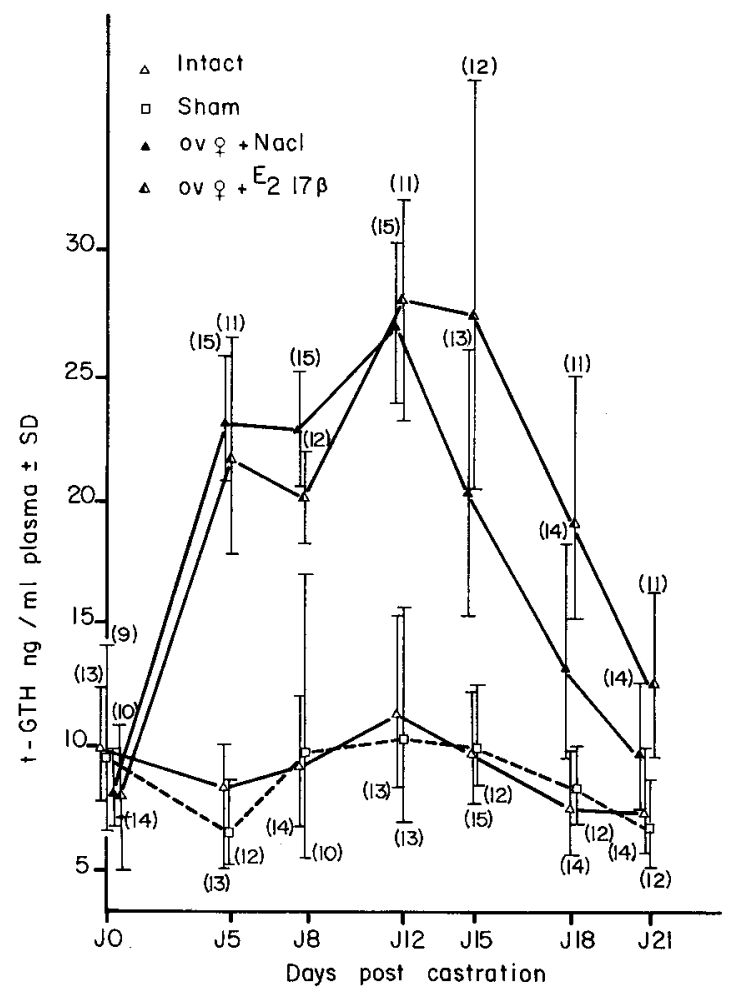

FIG. 1. - Change in the level of plasma GTH after ovariectomy at the end of vitellogenesis in the roinbow trout. 
Estradiol treatment did not change the castration response, at least during the first 3 weeks of treatment.

Experiment 2 : Castration during germinal vesicle migration. - Ovariectomy caused a rise in circulating GTH $(P<0.005$ compared to controls from day 3$)$ in all the females (fig. 2A), but detailed analysis of the results (fig. 2B) shows that there are two types of females. One-half evidenced a very quick rise in GTH : the original level was increased sixfold from post-surgical day 3 and remained that way up to the end of the experiment (day 14); the others had a slower GTH rise which only reached the level of the precedent group at post-surgical day 14.

Two types of females were also identified (fig. 2C) among the castrated fish given estradiol supplementation. One group of 5 showed a significant GTH elevation in the week after surgery but that rise was temporary. The other group of 6 females showed no rise in GTH, their levels remaining comparable to those of the controls.
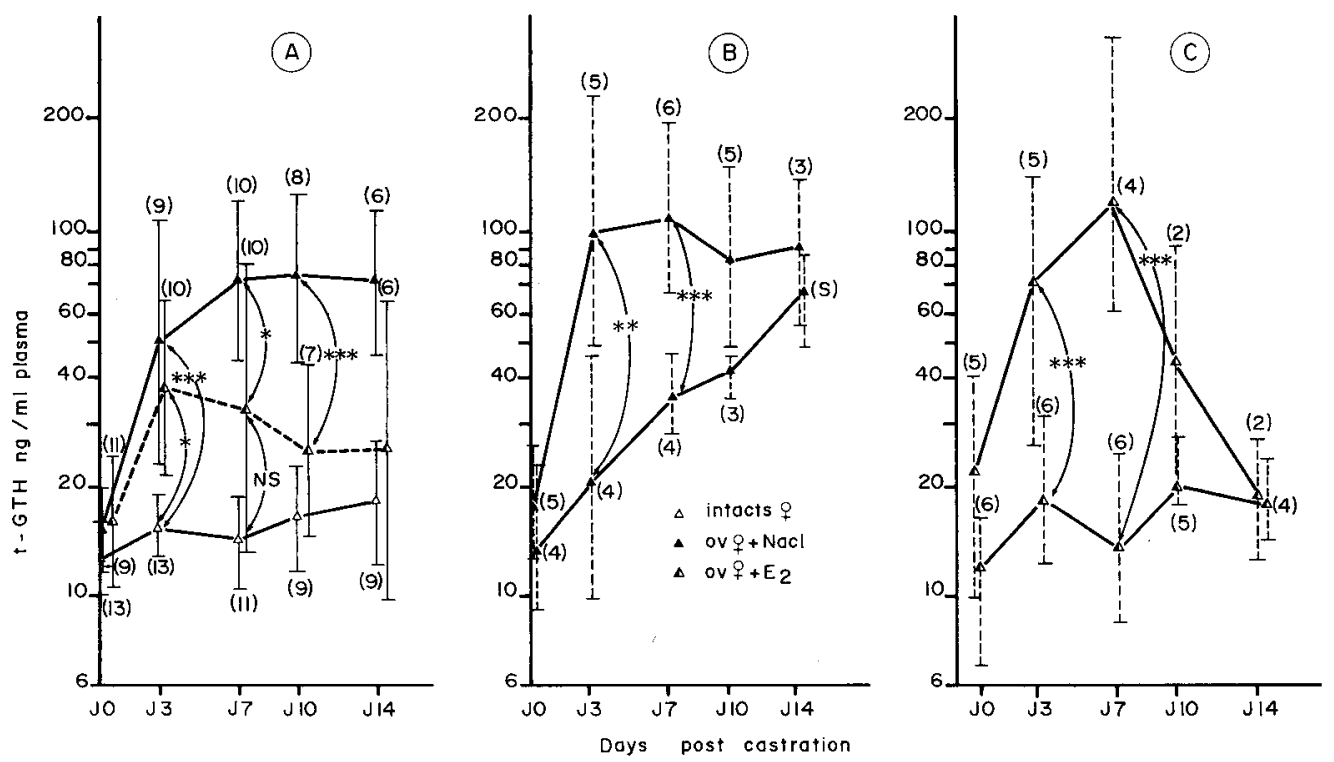

FIG. 2. - Change in plosma GTH after ovariectomy at the migratory germinal vesicle stage.

A. Overall results of all animals in all groups ; B. Castrated females divided into two groups ;

C. Castrated females supplemented with $17 \beta-E_{2}$ divided into two groups according to treatment response or non-response.

( ) : number of animals sampled ; A : \pm mean values ; $B, C$ : means with extreme values.

Experiment 3 : Post-ovulatory castration. - Due to the heterogeneous responses, it was necessary to present the individual result of each female (fig. 3). The circulating GTH increased in both the castrates (B) and the controls (A); the usual post-ovulatory elevation was observed in the latter. No difference was found between the two groups.

$\mathrm{E}_{2}$ treatment appeared to prevent the post-ovulatory GTH rise in the castrated females, at least temporarily, but because of the low survival rate in that group, we could not determine if there was a general augmentation after day 10 . 

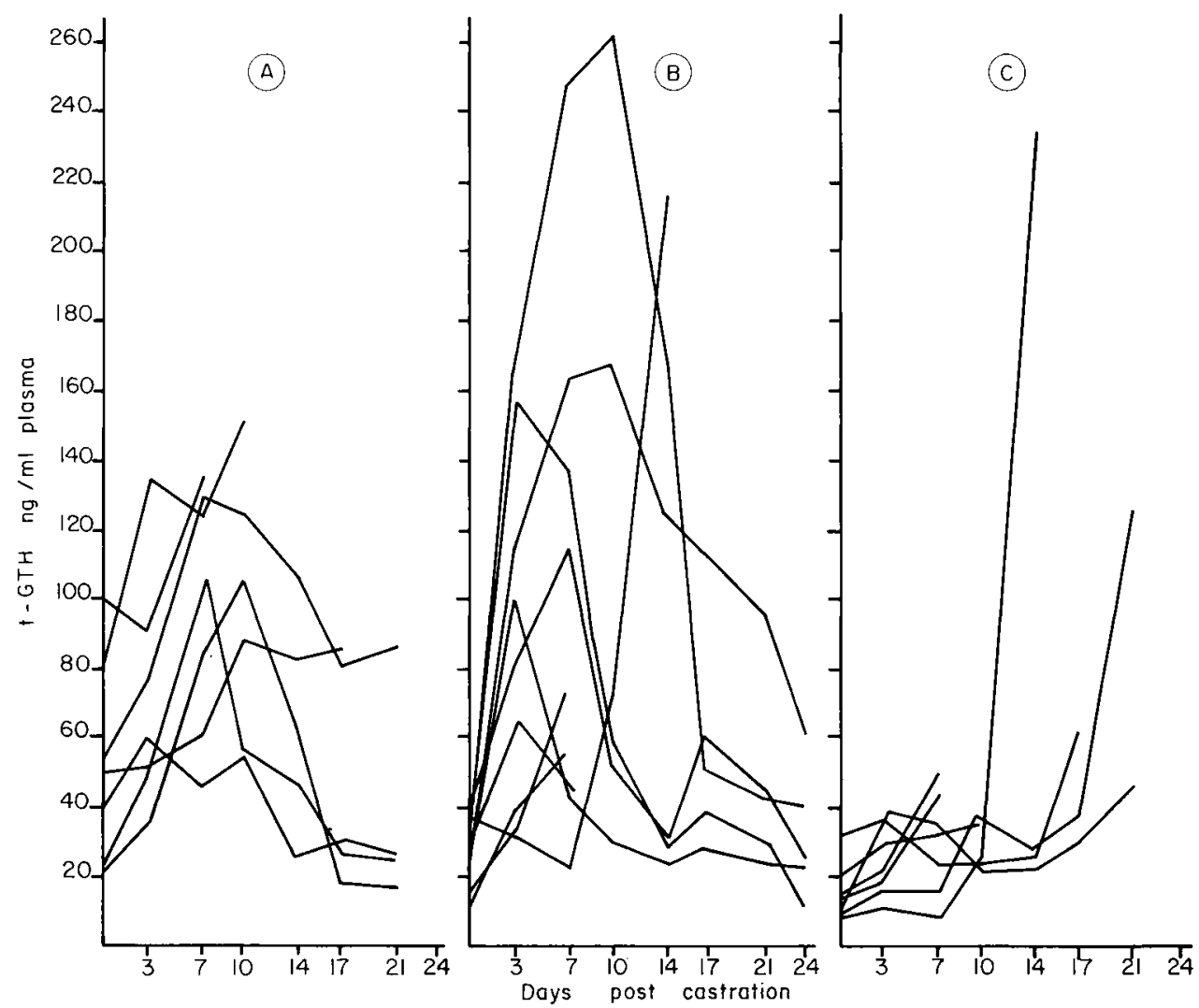

FIG. 3. - Plasma GTH changes after castration of the post-ovulatory stage. .

A : controls (intact females) ; B : ovariectomized females + saline ; C : ovariectomized females $+17 \beta-E_{2}$.

\section{Discussion.}

These results show negative gonadal feedback on pituitary (maturational hormone) secretion in female rainbow trout at the end of gametogenesis. We observed a marked effect of ovariectomy at the end of vitellogenesis and a variable effect during germinal vesicle migration. There was no gonadal feedback at the post-ovulatory stage. The effect of supplementing with $17 \beta-E_{2}$, one of the well-quantified steroids in trout plasma, was gradual, i.e. there was no effect at the end of vitellogenesis, partial effect when the germinal vesicle migrated, and a marked effect, at least temporarily, during the post-ovulatory period. The gonadal feedback found at the end of vitellogenesis did not appear to be induced by $E_{2}$. However, there are some limitations to our observations. We do not know how the $E_{2}$, injected into the circulation by way of the dorsal musculature, was taken up. It is presumed that any injection into the dorsal sinus would be taken up by the lymphatic system (Smith and Bell, 1975) and pass 
rapidly into the systemic circulation, but $E_{2}$ injected as microcrystals might not favourize uptake. Thus, due to the form, administration method and possible half-life variations of the hormone, we could not determine the efficiency of supplementary $E_{2}$.

Nevertheless, as the supplementation method was the same for all the fish, the two types of response at the migratory germinal vesicle (GV) stage might result from wide individual divergencies in the time-lag between detection of the migratory germinal vesicle and ovulation. Moreover, the definition of the studied stages is rather general, and the observed variations might be owing to more subtle physiological stages which were not detected by our method of classification.

The $\mathrm{GV}^{+}$stage would thus be a transitory period during which the hypothalamopituitary axis would be sensitized to $E_{2}$ effect either by modification of steroid half-life or by the presence or absence of circulating estradiol neutralizing protein. $E_{2}$ injection at the end of vitellogenesis and at the onset of germinal vesicle migration does not permit high plasma $E_{2}$ levels to be maintained, and the pre-ovulatory GTH rise is not prevented (Fostier, personal communication). Therefore, when $E_{2}$ is efficient, we cannot say where it acts, but since the central nervous system of fish can bind steroids, we may expect it to act on the hypothalamus (Peter, 1970 ; Billard and Peter, 1977).

It is possible that low or non-existent ovarian feedback on the pituitary at the postovulatory stage might cause plasma GTH to rise in normal physiological conditions, but this hypothesis raises questions because secretion may still increase if the eggs are left in the common cavity (Jalabert and Breton, 1980).

But this rise lasts only a short time (about 28 days), being about as brief as the postcastration elevation, and secretion could stop due to exhaustion of the pituitary gonadotropic cells. It has been shown that 4 weeks after ovariectomy of trout, the gonadotropic cells are characterized by the disappearance of secretory granules, suggesting that the cells are at least partially exhausted (Peute et al., 1978 ; Peute et al., 1980).

Several factors may be involved in negative gonadal feedback on the central nervous system. Some sex steroids such as testosterone, found in salmonid females (Campbell et al., 1980 ; Scott et al., 1980) and also quantified in the plasma of that species throughout the reproductive cycle (van Bohemen and Lambert, 1981), or 17 $\beta, 20 \alpha-$ progesterone (Jalabert et al., 1976) may play a role as well as other inhibitory factors in males (Breton and Billard, 1980).

Reçu en janvier 1981. Accepté en juin 1981.

Résumé. Afin de déterminer l'existence d'un contrôle des gonades sur le niveau de GTH plasmatique, des truites arc-en-ciel ont été ovariectomisées à trois stades du cycle de reproduction : en fin de vitellogenèse, au cours de la migration de la vésicule germinative et en période post-ovulatoire. Pour chacune des expériences, on disposait d'un lot d'animaux témoins et d'un lot d'animaux castrés recevant deux fois par semaine une injection d'une solution saline physiologique ef d'un lot d'animaux castrés supplémentés deux fois par semaine en $17 \beta$-estradiol $(200 \mathrm{\gamma} / \mathrm{kg})$ à partir du jour de l'opération. Des prélèvements de sang étaient effectués deux fois par semaine sous héparine filtrée et les dosages de GTH étaient effectués par radioimmunologie.

Les réponses à la castration varient fortement en fonction de la période de castration, de même que les réponses à une supplémentation en estradiol : en fin de vitellogenèse, la castration provoque une élévation significative du niveau d'hormone gonadotrope $\left(P<0,001\right.$ dès le $5^{e}$ jour post opératoire) ef la réponse est homogène pour tous les animaux. 
Dans les conditions d'administration, l'estradiol n'empêche pas cette montée. Au cours de la migration de la vésicule germinative, les réponses à la castration et à une supplémentation en estradiol varient selon les animaux : l'ovariectomie provoque une augmentation significative de GTH chez toutes les femelles ( $P<0,005$ au bout du $3^{e}$ jour), mais elle est rapide chez 5 animaux ef lente chez les 4 autres. L'esiradiol ne prévient la montée de GTH que chez 6 femelles. Au stade post-ovulatoire, on n'a pas pu mettre en évidence de différences significatives entre les animaux témoins ef les animaux castrés et l'estradiol empêche au moins temporairement, la montée post-ovulatoire de GTH normalement observée. II est dès lors possible que d'autres facteurs soient impliqués dans le rétrocontrôle des gonades sur l'axe hypothalamo-hypophysaire.

\section{References}

BILLARD R., 1978. Testicular feed-back on the hypothalamo-pituitary axis in rainbow trout (Salmo gairdneri). Ann. Biol. anim. Bioch. Biophys., 18, 813-818.

BILLARD R., BRETON B., FOSTIER A., JALABERT B., WEIL C., 1978. Endocrine control of the teleost reproductive cycle and its relation to external factors : salmonid and cyprinid models, 37-48. In GAILLARD P. J., BOER H. H., Comp. Endocrinol., Elsevier/North Holland, biochem. Press, Amsterdam.

BILLARD R., PETER R. E., 1977. Stimulation of gonadotropin secretion after castration in rainbow trout. Gen. comp. Endocrinol., 33, 163-165.

BILLARD R., RICHARD M., BRETON B., 1976. Stimulation de la sécrétion gonadotrope hypophysaire après castration chez la truite arc-en-ciel. Variation de la réponse au cours du cycle reproducteur. C. R. Acad. Sci. Paris, Sér. D, 283, 171-174.

BRETON B., BILLARD R., 1980. Mise en évidence d'une régulation non stéroödienne d'origine testiculaire sur la sécrétion d'hormone gonadotrope (GTH) chez la truite arc-en-ciel. C. R. Acad. Sci. Poris, Sér. D, 290, 1091-1094.

BRETON B., JALABERT B., FOSTIER A., 1975. Induction de décharges gonadotropes hypophysaires chez la carpe (Cyprinus carpio L.) à l'aide du citrate de cisclomiphène. Gen. comp. Endocrinol., 25, 400-404.

BRETON B., JALABERT B., REINAUD P., 1976. Purification of gonadotropin from rainbow trout (Salmo gairdneri) pituitary glands. Ann. Biol. anim. Bioch. Biophys., 16, 25-36.

BRETON B., KANN G., BURZAWA-GERARD E., BILLARD R., 1971. Dosage radioimmunologique d'une hormone gonadotrope de carpe (Cyprinus carpio L.). C. R. Acad. Sci. Paris, Sér. D, 272, 1515-1517.

BRETON B., PRUNET P., REINAUD P., 1978. Sexual differences in salmon gonadotropin. Ann. Biol. anim. Bioch. Biophys., 18, 759-765.

CAMPBELL C. M., FOSTIER A., JALABERT B., TRUSCOTT B., 1980. Identification and quantification of steroids in the serum of rainbow trout during spermiation and oocyte maturation. J. Endocrinol., 85, 371-378.

CRIM L. W., EVANS E. M., 1979. Stimulation of pituitary gonadotropin by testosterone in juvenile rainbow trout (Salmo gairdneri R.). Gen. comp. Endocrinol., 37, 192-196.

CRIM. L. W., IDLER D. R., 1978. Plasma gonadotropin, estradiol, and vitellogenin and gonad phosvitin levels in relation to the seasonal reproductive cycles of female brown trout. Ann. Biol. anim. Bioch. Biophys., 18, 1001-1006.

DADZIE S., HYDER M., 1976. Compensatory hypertrophy of the remaining ovary and the effects of methallibure in the unilaterally ovariectomized Tilapia aurea. Gen. comp. Endocrinol., 29, 433-440.

DE VLAMING, 1974. Environmental and endocrine control of teleost reproduction. In Control of sex in fishes. SCHRECK C. B., Virginia Polytech. Inst. State Univ. Blacksburg, U. S. A.

FEBVRE A., LAFAURIE P., 1971. Le lobe distal de l'hypophyse de Serranus scriba (Linné) et Serranus cabrilla (Linné) castrés et action du monobenzoate d'œstradiol. Vie ef milieu, 213-230.

FOSTIER A., WEIL C., TERQUI M., BRETON B., JALABERT B., 1978. Plasma estradiol $17 \beta$ and gonadotropin during ovulation in rainbow trout (Salmo gairdneri R.). Ann. Biol. anim. Bioch. Biophys., 18, 929-936. 
JALABERT B., BRETON B., 1980. Evolution de la gonadotropine plasmatique t-GTH après ovulation chez la truite arc-en-ciel (Salmo gairdneri R.) et l'influence de la rétention des ovules. C. $R$. Acod. Sci. Paris, Sér. D, 290, 1431-1434.

JALABERT B., BRY C., BRETON B., CAMPBELL C., 1976. Action de la $17 \alpha$-hydroxy-20 $\beta$-dihydroprogesterone sur la maturation ef l'ovulation in vivo ef sur le niveau d'hormone gonadoirope plasmatique, t-GTH, chez la truite arc-en-ciel (Solmo gairdneri R.) et l'influence de la rétention des ovules. C. R. Acad. Sci. Paris, Sér. D, 290, 1431-1434.

MAISSE G., DORSON M., TORCHY C., 1980. Inactivation de deux virus pathogènes chez les salmonidés (virus de la nécrose pancréatique infectieuse et de la septicémie hémorragique virale) par les rayons ultraviolets. Bull. fr. Pisc., 278, 34-40.

McBRIDE J.R., VON OVERBEEKE A. P., 1969. Cytological changes in the pituitary gland of the adult sockeye salmon (Oncorhynchus nerka) after gonadectomy. J. Fish Res. Bd Can., 26, 11471156.

OLIVEREAU M., CHAMBOLLE P., 1978. Ultrastructure des cellules gonadotropes de l'anguille normale et après injection d' $E_{2}$. C. R. Acad. Sci. Paris, Sér. D, 287, 1409-1412.

OLIVEREAU M., OLIVEREAU J., 1979a. Effect of estradiol $17 \beta$ on the cytology of the liver, gonads and pituitary, and on plasma electrolytes in the female freshwater eel. Cell Tissue Res., 199, 431 454.

OLIVEREAU M., OLIVEREAU J., 1979b. Estradiol positive feed-back on gonadotropic (GTH) cells in freshwater male silver eels. Gen. comp. Endocrinol., 39, 247-261.

PANDEY S., HOAR W. S., 1972. Induction of ovulation in goldfish by clomiphene citrate. Can. J. Zool., 50, 1679-1680.

PETER R. E., 1970. Hypothalamic control of thyroid gland activity and gonadal activity in the goldfish., Carassius auratus. Gen. comp. Endocrinol., 14, 334-356.

PEUTE J., GOOS H. J., DE BRUYN G. A., VAN OORDT W. J., 1978. Gonadotropic cells of the rainbow trout pituitary during the annual cycle. Ultrastructure and hormone content. Ann. Biol. anim. Bioch. Biophys., 18, 905-910.

PEUTE J., TERLOU M., GOOS H. J. Th., VAN OORDT P. G. W. J., 1980. Effect of ovariectomy on gonadotrophs and NLT of the rainbow trout. Gen. comp. Endocrinol., 40, 340.

SCOTT A. P., BYE V. J., BAYNES S. M., 1980. Seasonal variations in sex steroids of female rainbow trout (Salmo gairdneri Richardson). J. Fish Biol., 17, 587-592.

SINGH T. P., SINGH A. K., 1979. Ovarian activity and total gonadotrophin, and gonadotrophin releasing hormone levels in response to some synthetic non steroïdal ovulating agents in the catfish, Heteropneuste fossilis (Block). J. Endocrinol., 82, 341-345.

SMITH L. S., BELL G. R., 1975. A practical guide to the anatomy and physiology of Pacific salmon Miscellaenous. Spec. Publ., 27, Dept Environm. Fish. mar. Service. Ottawa.

SUNDARARAJ B., GOSWAMI S. V., 1968. Effect of $E_{2} 17 \beta$, progesterone and testosterone on the pituitary and ovary of catfish, Heferopneuste fossilis (Block). J. exp. Zool., 169, 211-228.

UEDA H., TAKAHASHI H., 1980. Responses of two different types of pituitary gonadotrophs of the loach, Misgurnus anguillicaudatus to gonadectomy and to exogenous sex steroids. Gen. comp. Endocrinol., 40, 463-472.

VAN BOHEMEN C. G., LAMBERT J. G. D., 1981. Oestrogen synthesis in relation to oestrone, oestradiol and vitellogenin plasma levels during the reproductive cycle of the female rainbow trout, Salmo gairdneri. Gen. comp. Endocrinol. 45, 105-114.

WEIL C., BILLARD R., BRETON B., JALABERT B., 1978. Pituitary response to LH-RH at different stages of gametogenesis in the rainbow trout (Salmo gairdneri). Ann. Biol. anim. Bioch. Biophys., 18, 863-869.

WHITEHEAD C., BROMAGE N. R., FOSTER J. R. M., MATTY A. J., 1978. The effects of alterations in photoperiod on ovarian development and spawning time in the rainbow trout (Salmo gairdneri). Ann. Biol. anim. Bioch. Biophys., 18, 1035-1043. 